\title{
Semen extenders: An evaluative overview of preservative mechanisms of semen and semen extenders
}

\author{
Ghadeer Sabah Bustani1 ${ }^{1}$ and Falah Hasan Baiee ${ }^{2}$ (D) \\ 1. College of Dentistry, The Islamic University, Najaf, Iraq; 2. Department of Clinical Science, Faculty of Veterinary \\ Medicine, University of Kufa, Kufa 54003, Najaf, Iraq. \\ Corresponding author: Ghadeer Sabah Bustani, e-mail: bustani@iunajaf.edu.iq \\ Co-author: FHB: falahhali@uokufa.edu.iq \\ Received: 19-12-2020, Accepted: 25-03-2021, Published online: 20-05-2021
}

doi: www.doi.org/10.14202/vetworld.2021.1220-1233 How to cite this article: Bustani GS, Baiee FH (2021) Semen extenders: An evaluative overview of preservative mechanisms of semen and semen extenders, Veterinary World, 14(5): 1220-1233.

\begin{abstract}
Reproduction is fundamental for all living things as it ensures the continued existence of a species and an improved economy in animal husbandry. Reproduction has developed since history, and diverse processes, such as artificial insemination and in vitro fertilization, have been developed. Semen extenders were discovered and developed to protect sperm from harmful factors, such as freeze and osmotic shock, oxidative stress, and cell injury by ice crystals. Semen extenders preserve sperm by stabilizing its properties, including sperm morphology, motility, and viability and membrane, acrosomal, and DNA integrity. Therefore, semen extenders must provide a favorable $\mathrm{pH}$, adenosine triphosphate, anti-cooling and anti-freeze shock, and antioxidant activity to improve semen quality for fertilization. Hence, this review provides precise data on different semen extenders, preservative mechanisms, and essential additives for semen extenders in different animals.
\end{abstract}

Keywords: additives to semen extenders, artificial insemination, cryopreservation, egg yolk-based extenders, lipid peroxidation, semen extenders.

\section{Introduction}

Artificial insemination (AI) is a powerful and unique technique for fertilizing the females of most mammals. The first animal was conceived using AI in 1784, and the first trial to produce straw for AI was at the beginning of the $20^{\text {th }}$ century [1]. AI was intended to increase the number of insemination doses from a single ejaculate but was unsuccessful because of the absence of sperm-washing procedures for both chilled or frozen-thawed semen of the male donor. These techniques are considered the foundation stone in the history of AI [1]. Moreover, AI is widely applied in cattle [2] and humans [3] but less in sheep [4], buffalos [5], horses [6], deer [7], and other mammals [8]. To improve economic efficiency, AI can impact different productivity projects, such as cattle and sheep husbandry and increasing weaning weight. Therefore, AI has a remarkable ability to impact economic feasibility [9].

Furthermore, AI needs fresh or well-preserved semen, and $95 \%$ of all AI is accomplished using preserved semen [10]. Thus, semen must be preserved in a perfect medium to maintain its quality [10-12]. Accordingly, it is necessary to develop and evaluate semen extenders used to preserve semen during chilling or cryopreservation [13].

Copyright: Bustani and Baiee. Open Access. This article is distributed under the terms of the Creative Commons Attribution 4.0 International License (http://creativecommons.org/licenses/ by/4.0/), which permits unrestricted use, distribution, and reproduction in any medium, provided you give appropriate credit to the original author(s) and the source, provide a link to the Creative Commons license, and indicate if changes were made. The Creative Commons Public Domain Dedication waiver (http:// creativecommons.org/publicdomain/zero/1.0/) applies to the data made available in this article, unless otherwise stated.
This review provides precise data on semen extenders, semen preservation mechanisms, and essential additives for semen extenders in different animals.

\section{Preservation of Semen}

The two primary techniques for semen storage are chilling and cryopreservation. For the chilling technique, semen is stored at $4-5^{\circ} \mathrm{C}$ for 3 days for maximum and best results. In the cryopreservation technique, semen is exposed to freezing for $3 \mathrm{~h}$ at $4^{\circ} \mathrm{C}$. Meanwhile, it is filled into $0.25-\mathrm{mL}$ straws and finally preserved and stored in liquid nitrogen for years [14]. Therefore, the crucial factors for long-term semen preservation to retain its quality include cooling for 2-3 h, adding a cryoprotectant, and freezing in liquid nitrogen [15].

\section{Cooling Temperature for Semen Preservation}

Temperature is decreased to induce sperm inactivity during storage in liquid form. The globally accepted cooling temperature is between $4^{\circ} \mathrm{C}$ and $5^{\circ} \mathrm{C}$ to maintain semen quality and reduce gamete metabolism in dogs[16], stallions [17], bulls [18], goats [19], and rams [20], whereas in boars, the diluted liquid semen must be kept between $15^{\circ} \mathrm{C}$ and $17^{\circ} \mathrm{C}$ [21]. Mammalian sperm cells, especially for rams [22], boars [23], bulls [24], stallions [12], and men [25], are damaged by rapid temperature drop. The temperature of post-chilled semen may not be as harmful to the intactness of the male sperm as the post-thawed technique, which results in low spermatozoal value [26]. A crucial advantage linked to using chilled semen is the high fertility percentage compared with the 
freeze-thawed semen, which decreases the insemination dose and increases the dose number, therefore, reducing storage expenses and easing the use of AI [27]. Moreover, the lifespan of chilled semen in the female reproductive tract is longer than that of frozen semen and with a higher fertilization rate [28]. Singh et al. [29] found that soybean-based diluent at $25 \%$ gave good quality values for bull semen at $5^{\circ} \mathrm{C}$ at different time intervals. Studies showed that the supplementation of different soybean lecithinconcentrations in Tris-based semen extenders (containing 2\% virgin coconut oil) increased the functional parameters of post- chilled bull semen [30].

\section{Cryopreservation of Semen}

Cryopreservation is the freezing of sperm, a technique used to keep cells and tissues in a vital state at $-196^{\circ} \mathrm{C}$ in liquid nitrogen. The use of liquid nitrogen started in the modern cryobiology era [31]. Furthermore, other advantages of cryopreservation include the long-distance transportation of valuable genetic materials and preventing the spread of pathogens [32].

Cryopreserved bull semen has been used commercially in cattle for decades since the data illustrated that the conception rate of the cryopreserved semen using AI technique is acceptable compared with natural mating [33,34]. Thus, a single dose of cryopreserved semen can achieve an equivalent in vivo fertilization 8 times more than that of fresh semen $[35,36]$. Semen cryopreservation generates free radicals due toexposure to atmospheric oxygen, and removes seminal plasma from the sperm cells. This results in the production of lipid peroxidation from sperm cells and, consequently, increases in reactive oxygen species (ROS) formation [37]. Furthermore, semen cryopreservation has no standard protocol applied in most previous studies $[38,39]$.

The improvement in semen extenders and cryopreservation techniques has significantly reduced the harmful effects of cryopreservation. However, cryopreservation still causes sperm damage in humans and various animals $[40,41]$.

\section{Factors that Determine Sperm Cryo-survival}

The challenge during cryopreservation is not sperm cells' ability to resist the storage period in liquid nitrogen but crossing the intermediate temperature zone between $-15^{\circ} \mathrm{C}$ and $-60^{\circ} \mathrm{C}$. The cells must go through these temperatures twice, first during cooling and then thawing, causing injurious effects on the integrity of the sperm plasma membrane, acrosome, and nucleus; mitochondrial function; and sperm motility $[32,42]$.

\section{Cryopreservation techniques}

Different cryopreservation techniques include conventional freezing, directional freezing, and sperm vitrification [43].

\section{Conventional freezing techniques}

Calling star-shaped ice crystal freezing is used in the manual freezing technique [43], where the semen is placed in contact with liquid nitrogen vapor at a height $4-5 \mathrm{~cm}$ above for $\leq 15-10 \mathrm{~min}$ before storage in liquid nitrogen. The freezing rate is approximately $60^{\circ} \mathrm{C} / \mathrm{min}[15,43,44]$. The conventional technique varies among species depending on sperm quality or cryo-survivability after freeze-thawing [44].

\section{Directional freezing techniques}

This technique is based on a multi-thermal gradient approach $[45,46]$. After dilution with a freezing extender, semen is chilled to $4-5^{\circ} \mathrm{C}$ at $0.3^{\circ} \mathrm{C} / \mathrm{min}$ and packaged in prechilled hollow tubes $(5,8$, or $12 \mathrm{~mL})$. Tubes are advanced through a linear temperature gradient, from $5^{\circ} \mathrm{C}$ to $-50^{\circ} \mathrm{C}$ at a constant velocity of $1 \mathrm{~mm} / \mathrm{s}$. Then, seeding is done for $60 \mathrm{~s}$ through a cold block at its other end, and tubes are moved to a collection chamber $\left(-100^{\circ} \mathrm{C}\right)$. These tubes are collected and transferred into liquid nitrogen for storage [43,47].

\section{Sperm vitrification techniques}

Vitrification is a process of transforming a solution containing a high concentration of cryoprotectant in a glass-like state without ice crystal formation through an ultra-rapid cooling process [48]. The high cooling rate, high viscosity, and low volume enable vitrification for sperm preservation [49]. In humans, vitrified sperm exhibits high post-thaw quality. Hence, vitrification is introduced by solidifying the solution into a glassy state without causing any crystallization in a fast and inexpensive manner. Holding solution is a significant component for vitrification prepared with N-2-hydroxyethylpiperazine-N-2-ethane sulfonic acid-buffered Medium 199 and 20\% of calf bull serum [50].

\section{Cryoprotectants Substance}

The various anti-freezing cryoprotectants are dimethyl sulfoxide (DMSO) and propylene glycol. During freezing and thawing of isolated cells, mostly $5-15 \%$ cryoprotectant concentration must be maintained for better results [51].

\section{Development of semen extender}

Experts have developed media for sperm survival during the cooling and freezing techniques [15]. Many challenges, such as media toxicity [52], irregular $\mathrm{pH}$ [53], ROS [54], energy source [55], sperm membrane damage [24], and cryo-shock preservatives [56], were faced and have been resolved. Extenders protect sperm, conserve motility, and fertility over time by stabilizing the plasmalemma, provide energy substrates, and prevent harmful effects of $\mathrm{pH}$ and osmolarity changes [57]. These solutions facilitate the increase in fertilization rate using high-quality extenders during chilling and cryopreservation. Therefore, a better quality of semen extenders and additives should be added to increase 
semen quality and increase the rate of sperm fertilization $[15,58]$.

\section{Semen extender}

Semen extenders are used as a medium for preserving sperm to enable fertilization. Semen extenders can also maintain and preserve sperm metabolic processes, control the $\mathrm{pH}$ of the medium during and after post-thawing, control bacterial transmission and contamination, and reduce cryogenic damage $[10,59]$. Likewise, semen extenders must provide other characteristics, such as maintaining the $\mathrm{pH}$ at 6.8-7.2 [53], provide energy [60], antioxidant to reduce the oxidative stress [61], antibiotics to prevent contamination [8], and anti-freezing shock [62,63]. These properties keep the sperm storage and transport and enable it to be used in AI in vitro fertilization, intracytoplasmic sperm injection, and research studies. Extenders appear in two forms: Chilled (liquid form) for an average of 3 days and cryopreserved for years [64]. At present, several extenders use different material sources such as animal source, egg yolk, skimmed milk [65], and plant source (soybean lecithin) [24], which provide various features and diverse problems according to the type of sperm extender and species. A good trait of soybean lecithin semen extender compared with the egg yolk extender is its more hygienic nature [66]. Egg yolk semen extenders are extensively used in the laboratory and field techniques because of their reasonable price and satisfactory results [24].

\section{Various Components of Semen Extender}

\section{Non-penetrating cryoprotectant source}

Skim milk and egg yolk are widely used as non-penetrating cryoprotectants for preserving sperm [67] of different male mammals, such as rams [68], bulls [59], stallions [65,69], boars [70], and humans [29]. Because these extenders might protect sperm membranes, their acrosome and DNA may be damaged because of high lecithin content [71]. Furthermore, soybean lecithin extenders can substitute the animal source as a source of lipid/lipoprotein [72].

\section{Egg Yolk}

The first professor who used egg yolk in semen extender was Philips in 1939 [73,74]. Egg yolk is the primary non-penetrate substance used in extenders to dilute semen and protect sperm from freeze shock during the chilling process. Egg yolk-based extender is commonly used in chilled, frozen semen, or both. It works as a reservoir of cholesterol and phospholipids that help protect the sperm cell membrane and acrosome against cryogenic injury. Furthermore, it prevents the loss of membrane phospholipids during the freezing process $[24,75]$. Egg yolk protein has hydrophobic properties, which cannot penetrate the cell wall of sperm. The low-density lipoprotein (LDL) of egg yolk maintains sperm membrane phospholipids throughout the cryopreservation processes $[24,76]$. The previous works have shown that sperm are protected during freezing by sequestering lipid-binding proteins from LDL in the egg yolk $[10,77,78]$. It is also considered a source of long-chain polyunsaturated fatty acids [79]. Besides, egg yolk contains lipid, protein and carbohydrate; it also contains minerals [10].

In contrast, several drawbacks against egg yolkbased semen extender use include the wide range of variability in the composition of egg yolk, the risk of disease transmission or bacterial contamination, and involvement of egg yolk in the microscopic examination of semen [39]. In general, egg yolk is used in semen extenders at different concentrations. However, it was also used at $20 \%(\mathrm{v} / \mathrm{v})$. Pieces of evidence revealed that LDLs are the egg yolk active ingredients responsible for sperm protection $[39,62]$.

Two types of extenders can be prepared from egg yolk:

\section{Egg yolk-based extender}

Here, the concentration of the egg yolk is $20 \%[24,62,80]$. Tris-buffered egg yolk extenders containing fructose and glycerol preserve the fertility of animal sperm at high extension rates. Poultry egg yolk can be used in the semen extenders; however, some studies show the possibility to use different egg yolks of animals, such as quail [81], turkey [82], duck [83], pigeon [82], goose [84], and ostrich [85]. Furthermore, researchers found that quail's egg yolk was improved the quality of semen higher than other birds egg yolk in terms of sperm motility and membrane integrity in ram [86] and bull [82] semen. Nonetheless, Swelum et al. [87] found that chicken egg yolk extenders are most recommended for buck semen.

\section{LDL extender}

LDL $(\mathrm{w} / \mathrm{v})$ was prepared in the laboratory following the method described by Moussa et al. [88]. They used poultry egg yolks to isolate LDL by ultracentrifugation $[22,88]$. Higher kinetic parameters were achieved using $2 \%, 4 \%$, and $8 \%$ LDL compared with $20 \%$ whole egg yolk in a Tris-milk extender and can lower the concentration of LDL, such as $2 \%$ associated with skimmed milk, which can be used for buffalo semen freezing [89].

According to several studies, egg yolk can be used with a $20 \%$ extender concentration $[24,82,90]$. In contrast, LDL can be used with $8 \%$ concentration $[91,92]$, and $2 \%$ LDL can be added solely with skimmed milk $[10,89]$. One significant challenge of using egg yolk and its derivatives is microbial contamination by Escherichia coli. Consequently, the fertilization capacity of contaminated semen could negatively affect the risk of microbial contamination associated with the egg yolk extender [93].

\section{Milk Sources}

Milk has been adapted for freezing mammalian semen mostly in a reconstituted form combined with arabinose, fructose, or egg yolk [10,44]. Skim milk 
proteins buffer semen $\mathrm{pH}$ and may also chelate any heavy metal ions [94]. An important milk compound is lactose, which is hydrophilic [95] and cannot diffuse the cell wall of the sperm cells, which protects the cell wall and prevents freeze shock [94-96]. Skim milk-based extender is superior to Tris-based extender based on semen preservation [96].

\section{Soybean Lecithin}

Soybean lecithin is an alternative for egg yolk and has been developed and used commercially for semen preservation [97]. Lecithin from soybean has been successfully used for semen cryopreservation [98]. Nowadays, researchers believe that extenders free from animal ingredients can decrease the risk of contamination transported by the animal source $[93,99]$. Therefore, soybean lecithin can be used as an alternative to milk- or egg yolk-based extenders for semen cryopreservation in bulls [24,30,98], boars [100], rams [101], dogs [102], deer [103], and camels [104].

The active components of soybean lecithin and egg yolk are entirely identical. These components are oleic acid, palmitic acid, stearic acid, and phosphatidylcholine. They prevent the diluted semen from freeze shock. The prevailing phospholipids in most mammalian biological membranes can confer physical stability to sperm cells [105]. On the basis of the research results of Gamal et al. [97] and MiguelJimenez et al. [98], soybean lecithin-containing diluter is possibly the best semen extender in bulls. Furthermore, El-Keraby et al. [106] found that the use of soybean-based extender increases sperm functional motility and reduces bacterial contamination in freezethawed bull semen. In a similar vein, Zhang et al. [107] ensured that the semen extender supplemented with soybean lecithin at $6 \%$ could upgrade sperm general and progressive motility and intact plasma membrane of post-thawed male boar sperm cells. Conversely, Singh et al. [26] and Rehman [71] discovered that 25\% soybean-based extender could improve sperm motility, sperm viability, sperm membrane integrity, and acrosomal integrity of bull sperm at $5^{\circ} \mathrm{C}$.

Depending on the results of Fathi et al. [108], using Tris-soybean lecithin-based extender at a 3\% concentration can be an appropriate alternative to either BullXcell ${ }^{\circledR}$ or OptiXcell $^{\circledR}$ in Damascus goat sperm cryopreservation.

\section{Glycerol as an Anti-shock}

After discovering glycerol as a remarkable cryoprotective agent for cryopreserving semen, using liquid nitrogen for adequate storage of frozen semen and AI has been a valuable and prevalent reproductive biotechnology for cattle genetic improvement [24]. Discovering the cryoprotective properties of glycerol in 1949 enabled the cryopreservation of different animals' sperm. [109]. Although different cryoprotective substances have been tested, including DMSO and propanediol, glycerol remains the favorite cryoprotectant for semen cryopreservation. Glycerol is a dominant cryoprotectant that can cross the cell membrane [101]. Studies stated that glycerol could be added to the semen at different temperatures. For instance, Evans et al. [110] observed that good semen protection was achieved at $30^{\circ} \mathrm{C}$. In contrast, another suggested that procedure for semen cryopreservation is adding glycerol at $5^{\circ} \mathrm{C}[14,111]$. Furthermore, studies also suggested that freezing extenders containing $3 \%$ glycerol combined with the straw freezing method using dry ice can produce the best post-thaw quality parameters for boar semen [112].

Fernández et al. [113] revealed that semen extenders containing egg yolk with $6 \%$ glycerol, followed by a rapid cooling rate, could yield higher postthaw outcomes for epididymal sperm compared with semen extenders containing 3\% glycerol. In another study, Martínez et al. [114] demonstrated that extenders containing $4 \%$ glycerol with $10 \%$ egg yolk are most suitable.

DMSO is a cryoprotectant that quickly enters sperm cells. It can be used to maintain the frozen sperm quality of bulls [115], boars [29], goats [116], and dogs [117]. In stallions, it is preferable to use DMSO or methyl formamide alone or combined with glycerol in skim milk extenders as cryoprotectants and alternatives to extenders containing glycerol only $[118,119]$. A study that compared three cryoprotectants, glycerol, ethylene glycol, and DMSO, revealed that the post-thaw motility and fertilization capacity of glycerol were higher than those of ethylene glycol and DMSO in dogs [120]. Earlier studies revealed that ethylene glycol is more dominantly used in buffalos [87], bulls [121], and sheep [122].

\section{Source of Energy}

Energy intake is responsible for the continuation of development and the function of all living cells, and gametes are no exception. Two metabolic pathways are producing adenosine triphosphate (ATP), that supplies energy for the main functions of sperm, which are oxidative phosphorylation and glycolysis [123]. Glycolysis occurs in the cytoplasm of sperm cells and provides energy for sperm metabolism [123]. Sugar, such as fructose and glucose, is considered the primary energy source in sperm cells [124]. However, fructose is the best sugar for maintaining functional membrane integrity, adequate sperm motility, andtonic after thawing [125].

Disaccharides are considered non-permeating agents for cells. These sugars interact with phospholipids of the plasma membrane, increasing sperm survival post-cryopreservation [126]. Moreover, lactate and pyruvate are significant energy sources in stallion sperm with dose effects on mitochondrial function, motility, and ROS production [127]. Trehalose can be used as a cryoprotectant in semen extenders to preserve the optimal quality of motility, viability, and membrane integrity of goat sperm cells compared with 
other types of sugar [128]. Glucose is a component of egg yolk and, therefore, can be used as an energy source. Nonetheless, other kinds of sugars, such as galactose, sucrose, maltose, xylose, and raffinose, have been successfully used for frozen bull semen $[10,11]$.

\section{Various Components as Additives to Semen Extenders}

To promote the quality of the extenders, several studies have been undertaken to use different materials and compounds such as those of plant origins [24,129-131], whole milk [54], fish oil [132], and honey [133], which contain natural compounds such as antioxidants $[24,130,131]$.

\section{Added Components of Plant Origin}

There is an international demand for using natural medical sources in semen extenders of different animals [134,135], for example, strawberry [136], green tea [134], virgin coconut oil [30], pomegranate [135], and Pinus brutia [137,138], among others. The effects of several plant extracts on fertility have been demonstrated as antioxidants in many animal species due to their free radical scavenging properties [139].

According to the results of El-Sheshtawy [136], he used a $1 \%-5 \%$ concentration of strawberry in Tris extender and improved semen parameters in cooling temperature and used strawberry at $3-6 \%$ concentration, which improved semen parameters in freezing temperature for bull semen.

Researchers found that supplementation of Triscitric acid extender with $1.0 \%$ green tea improved sperm parameters in both in vitro and in vivo fertilization, which decreased lipid peroxidation in buffalo bull sperm freezing and thawing processes [134].

For virgin oil addition, researchers found that Tris-based extenders containing $2 \%$ virgin oil did not improve the quality of parameters for freeze-thawed bull semen but enhanced the quality of parameters for chilled bull semen [30]

An experimental study illustrated that adding $P$. brutia to the semen extender does not improve parameters such as motility but prevents chromatin damage and reduces oxidative stress and sperm abnormalities when used at a concentration of $50 \mu \mathrm{g} / \mathrm{mL}$ [137].

\section{Added components of animal origin Honey}

Malik [133] found that adding honey to extenders significantly affected sperm motility before freezing and sperm abnormality of the freeze-thawed semen. Honey contains a high number of various simple sugars and antioxidants [140]. Furthermore, honey is also a highly concentrated product. It has a potential hyperosmotic extracellular environment around sperm cells that enhance the efflux of intracellular fluid, thereby minimizing the formation of ice crystals inside the sperm cytoplasm, which has been linked to sperm damage during cryopreservation [141]. This illustrated that using honey increased the quality of the semen after thawingcompared with using egg yolk extenders.

Yimer et al. [142] showed that adding honey to bull semen Tris extender at $2.5 \%$ was optimum to obtain improved semen cryopreservation results compared with Bioxcell ${ }^{\circledR}$. Another experiment [143] illustrated that adding different honey concentrations to extenders has various effects on the semen quality of different bull breeds. Jersey bull exhibited the best sperm quality compared with Mafriwal, Piedmontese, and Limousin bulls. Because El-Nattat et al. [144] considered that $1 \%$ concentration of honey additive to Bioxcell $^{\circledR}$ extender could be higher effectively when used in bull semen cryopreservation compared with Bioxcell ${ }^{\circledR}$ only identified as a control.

Moreover, Fakhrildin and Alsaadi [141] showed that adding of honey to the freezing semen medium of humans at $10 \%$ concentration to semen extender resulted in enhanced sperm post-thawing quality of most sperm parameters.

In addition, researchers have reported the benefits of using honey as a supplement in the cryopreservation semen media of various animals, such as goat [145], which act as natural antibiotics against pathogenic bacteria, hinder sperm survival, fertilizing ability, reduce the number of dead abnormal sperm, and acrosomal damage. Some studies showed that using 2.5\% honey might be an energy source to ram semen [146]. El-Sheshtawy et al. [147] illustrated that adding 3\% of honey in extenders as a cryoprotectant improved Arab stallion post-thawing sperm parameters.

\section{Fish oil}

Fish oil can improve semen performance after freeze-thawing and AI besides the type of extender shown in bulls. The addition of $150 \mathrm{mg} / 100 \mathrm{~mL}$ fish oil in the extender could positively enhance the quality of post-thawed semen of Kalang swamp buffalos [59]. Abdi-Benemar et al. [148] found that adding $0.30 \mathrm{~g}$ of fish oil per $100 \mathrm{~mL}$ of egg yolk-based extender resulted in an improved fertility capacity of ram and goat semen. Kaeoket et al. [149] found that adding fish oil to boar semen extender improves sperm motility, viability, and acrosomal integrity. The researcher also showed that fish oil supplementation has a beneficial effect on semen quality, except for in vitro evaluations [150].

Some studies reported that the addition of fish oil to feed supplements improved the semen quality and fertility rate of sheep [151], bulls [152], rams [153], boars [154], and stallions [155].

\section{Vitamins}

Vitamins are added to extenders to improve semen function parameters for liquid nitrogen storage or cryopreserved sperm cells because vitamins are non-enzymatic antioxidants [156-159].

\section{Vitamin $B_{12}$}

Adding Vitamin $\mathrm{B}_{12}$ to the extenders improved bull frozen semen quality, elevated the motility 
percentage of sperm cells, and improved movement characteristics $[68,86,160,161]$. Researchers found that the addition of $2.50 \mathrm{mg} / \mathrm{mL}$ Vitamin B to semen extenders improved bull frozen semen parameters and quality [161]. Furthermore, oral administration of $200 \mathrm{mg} / \mathrm{kg}$ body weight per day of Vitamin $\mathrm{B}_{12}$ could improve fresh and post-thawed sperm quality and fertility in male broiler breeders [159].

\section{Vitamin E}

Vitamin E is a cellular stabilizer of unsaturated lipids against oxidative deterioration, and hence, it maintains the structural and functional integrity at the subcellular level $[161,162]$. In general, Vitamin E is the primary component of the antioxidant system in sperm cells $[163,164]$. Furthermore, adding Vitamin E to Tris-egg yolk extenders at 60 and $120 \mu \mathrm{M}$ provides higher integrity to the plasma membrane, mitochondria, and kinematic parameters of sperm cells of rams [165], roosters [162], and bulls [164] post-cryopreservation.

\section{Vitamin $C$}

Vitamin $\mathrm{C}$ is the most crucial antioxidant in seminal fluid [166]. Researchers found that $0.9 \mathrm{mg} /$ $\mathrm{mL}$ of Vitamin $\mathrm{C}$ improves the longevity and quality of chilled sperm in Awassi ram semen stored at $5^{\circ} \mathrm{C}$. Furthermore, as an alternative to glutathione, Vitamin $\mathrm{C}$ is considered more efficient in protecting ram sperm viability and acrosomal integrity than Vitamin E because Vitamin c can neutralize $\mathrm{H}_{2} \mathrm{O}_{2}$ production in a hydrophilic environment $[167,168]$ by preventing peroxide formation [169]. However, higher concentrations of Vitamin C $(2.5 \mathrm{mM})$ proved to be harmful to sperm motility in freeze-thawed bull semen [168]. Studies in humans showed that a high concentration of Vitamin $\mathrm{C}$ in the range of 0.02-0.6 $\mathrm{mM}$ adversely affected sperm motility [170].

\section{Other Additions}

Several researchers have added various substances to semen extenders, such as milk, caseinate, and lactoferrin [120]. Other researchers added hormones, such as insulin [171], follicle-stimulating hormone [172], and testosterone [173], to the semen extenders. The addition of selenium improved male reproductive performance by potentiating semen quality and suppressing free radicals $[174,175]$. Selenium could decrease lipid peroxidation and increase antioxidants in rooster seminal plasma after the freezethawing process [176].

\section{Antibiotic addition to semen extenders}

Antibiotics are added to semen extenders to reduce microbial contamination of the external environment or during semen collection. Different antibiotics, such as penicillin and streptomycin, ceftiofur, apramycin, and aminoglycosides or linco-spectin + tylosin + gentamycin, have been added to semen extenders [10].

\section{Commercial extenders}

Several commercial extenders are used for diluting and preserving semen during cooling and cryoprotection. Optidyl ${ }^{\circledR}$ and Triladyl ${ }^{\circledR}$ (Biovet, France) are commercial extenders containing egg yolk and provide excellent protection for bull semen against freeze shock. It is usually used by many French AI centers [76]. Bioxcell ${ }^{\circledR}$ is a commercial extender that contains milk, egg yolk, or both [177]. Gent $^{\mathbb{B}}$ A (Minitüb GmbH, Tiefenbach, Germany) is a commercial extender containing egg yolk and is used for the preservation of semen for a long time [178]. BotuSemen ${ }^{\circledR}$ is a commercial extender that contains a skim milk base used for preserving frozen sperm of stallions [12]. EquiPlus ${ }^{\circledR}$ is a commercial extender that contains defined milk proteins used to preserve semen [26]. INRA $96^{\circledR}$ is a commercial extender that contains a caseinate used to preserve semen [179].

\section{Semen Assessment}

\section{Sperm motility}

The motility of sperm is the most critical parameter for evaluating male potential fertility [77], and it depends on mitochondrial function [180,181]. Motility includes total general motility, progressive motility, and kinematic parameters [181]. Sperm cells must possess high maintenance of sperm motility to ensure maximum potential fertility $[114,182]$. Moreover, the motility of sperm cells is also associated with sperm DNA defects. Furthermore, sperm motility is crucial for fertilization $[45,181]$. Immotile sperm and motility disorders of sperm are notable indicators of male infertility [183]. Therefore, microscopic examination and estimation of the percentage of forward movement of sperm are a standard test to indicate male fertility $[45,181]$.

The tail of mammalian sperm cells is represented by a single, specific type of motile cilium known as the sperm tail (flagellum) that generates its movement to propel the cell through the female reproductive tract and fertilize the oocyte [184]. Sperm cells rely on vigorous motility that is initiated once they are released. They reach capacitation, which is needed to hyperactivate the ability to perform the acrosome reaction and fertilization $[161,162]$. In general, the tail motion is generated by ATP. When activated, sperm cells exhibit vigorous motility and enter rapid consumption of intracellular energy in which ATP content could be relevant for fertilizing potential [185].

Computer-assisted sperm analysis has been used to collect data after reducing human inequality during semen estimation. Moreover, it could be noted that different sperm motilities deem a fundamental part of semen evaluation in almost all creatures [186]. The most critical kinetic parameters include curve-linear velocity, straight-line velocity, and average-path velocity [182]. 


\section{Sperm viability}

The viability of sperm cells is an essential aspect of ejaculation quality that determines competitive fertilization success, proportional to live sperm [187]. Spermatozoal viability is essential for motility and fertilizing ability. Once sperm viability is reduced, their ability to induce fertilization is decreased [58,187]. The percentage of live sperm cells was determined in the laboratory by identifying the number of sperms that did not take up the eosin-nigrosin stain [14,58,187].

\section{Sperm morphology}

Sperm morphology depends on spermiogenesis [188] or events that occur after spermiation [175]. Improper handling of semen samples because of lack of experience can cause challenges during the cooling and freezing processes. Furthermore, these challenges may lead to acrosomal damage and abnormality of sperm tails [189]. Sperm shape abnormality includes head defects, such as microcephaly and macrocephaly. Midpiece defects, such as proximal cytoplasmic droplets, distal midpiece reflexes, and segmental aplasia of the mitochondrial sheath, are common [190].

There are three theories about abnormal sperm that can be presumptive. The first theory suggests primary or secondary defects; the primary defect occurs at the seminiferous tubules in the progress of spermatogenesis. In contrast, the secondary sperm abnormality is caused by abnormal function of the epididymis or during semen handling after ejaculation [139]. The second theory ascribes the sperm defect to the relationship between sperm and the fertility of males. Therefore, it is defined as a major or minor defect. The major sperm defect can directly affect male fertility; however, the minor defect may not affect male fertility [191]. Whether the defects of sperm cells are compensable or un-compensable, it distinguishes between the types of sperm defect. This may be compensated for by increasing the numbers of sperm to overcome sperm defects [192]. The third theory states that sperm defects can be classified according to the defect site (head, midpiece, and tail). Sperm morphology can be evaluated either with non-stained wet models under phase-contrast microscopy orfixed and stained sperm cells with post-dried eosin-nigrosine stain under 100× magnification [193].

\section{Acrosomal Reaction}

The study of acrosomal integrity in mammalian species is a valuable tool in evaluating male subfertility and infertility. With advancements in microscopic visualization and cell-staining technology, methods for determining acrosomal integrity have been developed. The acrosome reaction is an exocytotic event initiated when sperm binds to the zona pellucida of an ovum. Once sperm binding occurs, the outer acrosomal membrane fuses with the overlying plasma membrane of the ovum [194]. The fusion of these membranes triggers vesiculation, a process where many small vesicles are created that allows for the dispersal of acrosomal enzymes [195,196]. The release of acrosomal enzymes enables the sperm cell to digest its way through the zona pellucida and begin the process of fertilization [197,198].

\section{Importance of an Intact Acrosome}

The ability of a sperm cell to undergo capacitation, acrosome reaction, and a fertilization event requires an intact acrosome at the time of ejaculation and after the freeze-thawing process. The disruption or damage to the acrosome is permanent and results in premature loss of acrosomal contents, ultimately preventing fertilization [199,200]. Moreover, damaged acrosomes do not undergo vesiculation properly but spontaneously rupture and defect fertilization in the end [199].

\section{Hypo-osmotic Swelling Test (HOST)}

The HOST evaluates the functional integrity of the sperm's plasma membranes. Although the HOST is a simple test, it is considered an indicator of fertility in some species as the viability of the sperm membrane is an essential requirement for fertilization [50,201]. HOST and the integrity of the acrosome could be associated with motility results. To evaluate the sperm membrane integrity using HOST, an aqueous solution is prepared with fructose and trisodium citrate in distilled water to produce a solution $(100 \mathrm{mOsm} / \mathrm{kg}$ $\mathrm{H}_{2} 0$ ) as described by Lamia et al. [202] and Kumar et al. [99].

\section{In vivo Fertility Evaluation}

It is crucial to examine the in vivo fertility test to provide comprehensive and perfect data. This test is considered the most important one for evaluating semen quality and provides information on the capability of sperm and pollination capacity of the ova after access to the female reproductive tract. Potential fertility depends on multiple parameters that require a multi-parametric analysis of sperm morphology, sperm motility, membrane status of sperm, sperm acrosome reaction, and genome integrity of sperm to provide a complete picture of a male's fertility potential. Moreover, the reliability of fertility prediction is reported to increase by combining several in vitro sperm quality parameters [180,181,203]. The difficulty of this assay is that it is a time-consuming and costly procedure as hundreds of successful inseminations are required.

\section{Lipid Peroxidation Test}

A typical trait of biological cell membranes is the asymmetrical organization of fatty acids (lipids) within the bilayer. The composition of lipids in most mammalian sperm cell membranes is different compared with that in somatic cells. Polyunsaturated fatty acids are found in high amounts in sperm cell membranes, and the ratio of saturated to unsaturated fatty acids in ruminants' sperm cell membranes is 
higher than in other animals. This makes sperm cell membranes more subject to damage by peroxidation, primarily when an ROS is present $[37,204]$. In contrast, controlling the release of molecular oxygen may result in less ROS production and hence maintain the fertilizing ability, acrosome reaction, and capacitation of sperm [37,205].

\section{Conclusion}

Our review article provides a comprehensive analysis of different semen extenders, the mechanisms of preserving semen, and essential additives for semen extenders in different animals. The study can be used as a road map for future studies to develop appropriate semen preservation and $\mathrm{AI}$ techniques.

\section{Authors' Contributions}

FHB: Conceptualized, drafted, and supervised the final version as well as editing of the review. GSB: Collected relevant literature, contributed to the original draft, data curation, investigation, and review of the manuscript. All authors read and approved the final manuscript.

\section{Acknowledgments}

We would like to thank Prof. Abbas H. J. Sultan, for English editing. The authors did not receive any funds for this study.

\section{Competing Interests}

The authors declare that they have no competing interests.

\section{Publisher's Note}

Veterinary World remains neutral with regard to jurisdictional claims in published institutional affiliation.

\section{References}

1. Ombelet, W. and Van Robays, J. (2015) Artificial insemination history: Hurdles and milestones. Facts Views Vis. Obgyn, 7(2): 137-143.

2. Berry, D.P., Ring, S.C., Twomey, A.J. and Evans, R.D. (2020) Choice of artificial insemination beef bulls used to mate with female dairy cattle. Int. J. Dairy Sci., 103(2): 1701-1710.

3. Henry, A.M.S., Raphael, O.E. and Carmen, A.M.M. (2019) Factors associated with successful homologous artificial insemination. Gynecol. Reprod. Health, 3(2): 1-5.

4. Alvarez, M., Anel-Lopez, L., Boixo, J.C., Chamorro, C., Neila-Montero, M., Montes-Garrido, R. and Anel, L. (2019) Current challenges in sheep artificial insemination: A particular insight. Reprod. Domest. Anim., 54(Suppl 4): 32-40.

5. Monteiro, B.M., de Souza, D.C., de Carvalho, N.A.T. and Baruselli, P.S. (2018), Effect of season on dairy buffalo reproductive performance when using P4/E2/eCGbased fixed-time artificial insemination management Theriogenology, 119(1): 275-281.

6. Landim-Alvarenga, F.C., Fernandes, C.B., Devito, L.G., Derussi, A.A.P., Blanco, I.D.P. and Alvarenga, M.A. (2018), New assisted reproductive technologies applied to the horse industry: Successes and limitations. Anim. Reprod., 5(3): 67-82.

7. Vincent, P., Underwood, S.L., Dolbec, C., Bouchard, N.,
Kroetsch, T. and Blondin, P. (2018) Bovine semen quality control in artificial insemination centers. Anim. Reprod., 9(3): 153-165.

8. Schulze, M., Nitsche-Melkus, E., Hensel, B., Jung, M. and Jakop, U. (2020) Antibiotics and their alternatives in artificial breeding in livestock. Anim. Reprod. Sci., 220(9): 106284.

9. Lamb, G.C. and Mercadante, V.R. (2016) Synchronization and artificial insemination strategies in beef cattle. Vet. Clin. Food Anim. Pract., 32(2): 335-347.

10. Raheja, N., Choudhary, S., Grewal, S., Sharma, N. and Kumar, N. (2018) A review on semen extenders and additives used in cattle and buffalo bull semen preservation. $J$. Entomol. Zool. Stud., 6(3): 239-245.

11. Rammutla, T.L. (2018) Effect of Different Disaccharides as Energy Supplements in Tris-Egg Yolk Semen Extender on the Quality of Cryopreserved Boer Goat Spermatozoa (Doctoral Dissertation).

12. Hernández-Avilés, C., Love, C.C., Serafini, R., RamírezAgámez, L., Friedrich, M., Ghosh, S. and Varner, D.D. (2020) Effects of glucose concentration in semen extender and storage temperature on stallion sperm quality following long-term cooled storage. Theriogenology, 147(7): 1-9.

13. Santos, M., Soares, F., Moreira, M. and Beirão, J. (2018) Evaluation of different extenders for the cold storage of meagre (Argyrosomus regius) semen. Aquac. Res., 49(8): 2723-2731

14. Baiee, F.H., Wahid, H., Rosnina, Y., Ariff, O.M., Yimer, N., Salman, H. and Khumran, A.M. (2017) Hypo-osmotic swelling test modification to enhance cell membrane integrity evaluation in cryopreserved bull semen. Pertanika J. Trop. Agric. Sci., 40(2): 259-268.

15. Baiee, F.H., Wahid, H., Rosnina, Y., Ariff, O., Yimer, N., Jeber, Z. and Harighi, F. (2018) Impact of Eurycoma longifolia extract on DNA integrity, lipid peroxidation, and functional parameters in chilled and cryopreserved bull sperm. Cryobiology, 80(2): 43-50.

16. Pignataro, T.A., Araújo, J.M.D., Silva, A.B.S., Freitas, M.L., Teixeira, H.C.A., Pivato, I. and Oliveira, R.A. (2020) Comparison of extenders and storage temperature in chilling canine semen. Ciênc. Anim. Bras., 21(1): 52499.

17. Trentin, J.M., Rodrigues, M.F., Pessoa, G.A., Fiorenza, M.F., Schenatto, R.O., de Araujo, L.B. and Rubin, M.I.B. (2017) Viability of pony stallion semen in different temperature and dilution. Acta Sci. Vet., 45(9): 1-8.

18. Dias, E.A.R., Campanholi, S.P., Rossi, G.F., Dell'Aqua, C.D.P., Junior, J.A.D., Papa, F.O. and Monteiro, F.M. (2018) Evaluation of cooling and freezing systems of bovine semen. Anim. Reprod. Sci., 195(8): 102-111.

19. Sadeghi, S., Del Gallego, R., García-Colomer, B., Gómez, E.A., Yániz, J.L., Gosálvez, J. and Silvestre, M.A. (2020) Effect of sperm concentration and storage temperature on goat spermatozoa during liquid storage. Biology, 9(9): 300

20. Acharya, M., Burke, J.M. and Rorie, R.W. (2019) Effect of semen extender and storage temperature on motility of ram spermatozoa. ARSci, 8(1): 14-30.

21. Prieto-Martínez, N., Bussalleu, E., Garcia-Bonavila, E., Bonet, S. and Yeste, M. (2014) Effects of Enterobacter cloacae on boar sperm quality during liquid storage at $17 \mathrm{C}$. Anim. Reprod. Sci., 148(1-2): 72-82.

22. Manjunath, P. (2018) New insights into the understanding of the mechanism of sperm protection by extender components. Anim. Reprod., 9(4): 809-815.

23. Luongo, C., Garrappa, G., Llamas-López, P.J., RodríguezTobón, E., López-Úbeda, R., Abril-Sánchez, S. and GarcíaVázquez, F.A. (2020) Effect of boar seminal dose type (cervical compared with post-cervical insemination) on cooling curve, sperm quality and storage time. Anim. Reprod. Sci., 212(1): 106236

24. Layek, S.S., Mohanty, T.K., Kumaresan, A. and Parks, J.E. 
(2016) Cryopreservation of bull semen: Evolution from egg yolk based to soybean-based extenders. Anim. Reprod. Sci., 172(9): 1-9.

25. Keshtgar, S., Bagheri, S. and Ebrahimi, B. (2018) Comparing human sperm quality preserved at two different temperatures; effect of trolox, coenzyme q10 and extracellular adenosine triphosphate. Iran. J. Med. Sci., 43(5): 541-545.

26. Singh, A.K., Singh, V.K., Narwade, B.M., Mohanty, T.K. and Atreja, S.K. (2012) Comparative quality assessment of buffalo (Bubalus bubalis) semen chilled (5 C) in egg yolkand soya milk-based extenders. Reprod. Domest. Anim., 47(4): 596-600.

27. Vishwanath, R. and Shannon, P. (2000) Storage of bovine semen in liquid and frozen state. Anim. Reprod. Sci., 62(1-3): 23-53.

28. Bucher, A., Kasimanickam, R., Hall, J.B., Dejarnette, J.M., Whittier, W.D., Kähn, W. and Xu, Z. (2009) Fixed-time AI pregnancy rate following insemination with frozen-thawed or fresh-extended semen in progesterone supplemented CO-Synch protocol in beef cows. Theriogenology, 71(7): 1180-1185.

29. Singh, A., Bhakat, M., Mohanty, T.K., Mondal, S., Yadav, S.K., Kumar, P. and Sinha, A.R.R. (2019) Effect of tris-egg yolk, soya milk, and liposome-based extenders on Sahiwal (Bos indicus) sperm quality during pre-and post-cryopreservation stages. Cryoletters, 40(2): 94-102.

30. Tarig, A.A., Wahid, H., Rosnina, Y., Yimer, N., Goh, Y.M., Baiee, F.H. and Ebrahimi, M. (2017) Effect of different concentrations of soybean lecithin and virgin coconut oil in Tris-based extender on the quality of chilled and frozen-thawed bull semen. Vet. World, 10(6): 672-678.

31. Gandini, L., Pallotti, F., Paoli, D. and Lenzi, A. (2017) Cryopreservation of Spermatozoa. Endocrinology of the Testis and Male Reproduction. p1235-1250.

32. Buranaamnuay, K., Tummaruk, P., Singlor, J., RodriguezMartinez, H. and Techakumphu, M. (2009) Effects of straw volume and Equex-STM ${ }^{\circledR}$ on boar sperm quality after cryopreservation. Reprod. Domest. Anim., 44(1): 69-73.

33. Abdulkareem, T.A., Eidan, S.M., Ibrahim, F.F., Ali, M.D., Abdul-Karim, M.G., Abdul-Rahman, Q.A. and Mohammed, O.A. (2017) Evaluation of some artificial insemination activities for cows in Iraq 1. Percentage of artificial insemination and natural mating for cows and reproductive efficiency according to the type of insemination. Anbar J. Agric. Sci., 15(2): 425-413.

34. Cueto, M.I., Fernandez, J., Bruno-Galarraga, M.M., Pereyra-Bonnet, F. and Gibbons, A. (2018) 196 fertilization rate in superovulated Criolla goats following artificial insemination or natural mating. Reprod. Fertil. Dev., 30(1): 238-238.

35. Andersson, M., Taponen, J., Koskinen, E. and Dahlbom, M. (2004) Effect of insemination with doses of 2 or 15 million frozen-thawed spermatozoa and semen deposition site on pregnancy rate in dairy cows. Theriogenology, 61(7-8): 1583-1588.

36. Silveira, E.C., Bortolloti, L.A., Morotti, F., SilvaSantos, K.C., Santos, G.M.G., Andrade, E.R. and Seneda, M.M. (2018) Insemination of four cows per dose of frozen semen with a fixed-time artificial insemination protocol. Anim. Reprod., 10(2): 124-126.

37. Bucak, M.N., Ateşşahin, A. and Yüce, A. (2008) Effect of antioxidants and oxidative stress parameters on ram semen after the freeze-thawing process. Small Rumin. Res., 75(2-3): 128-134.

38. Cardoso, R.D.C., Silva, A.R., Uchoa, D.C. and da Silva, L.D.M. (2003) Cryopreservation of canine semen using a coconut water extender with egg yolk and three different glycerol concentrations. Theriogenology, 59(3-4): 743-751.

39. Anzar, M., Rajapaksha, K. and Boswall, L. (2019) Egg yolk-free cryopreservation of bull semen. PLoS One,
14(10): e0223977.

40. de Menezes, E.B., van Tilburg, M., Plante, G., de Oliveira, R.V., Moura, A.A. and Manjunath, P. (2016) Milk proteins interact with goat Binder of SPerm (BSP) proteins and decrease their binding to sperm. Cell Tissue Res., 366(2); 427-442.

41. Makarova, N.P., Romanov, Y.A., Dolgushina, N.V., Parker, M.M. and Krasnyi, A.M. (2018) Comparative analysis of the expression of glutathione peroxidase and glutathione reductase genes in human sperm after cryopreservation. Bull. Exp. Biol. Med., 165(1): 166-170.

42. Medina-Robles, V.M., Duarte-Trujillo, A.S. and CruzCasallas, P.E. (2020) Crioconservación seminal en peces de agua dulce: Aspectos biotecnológicos, celulares y bioquímicos. Orinoquia, 24(2): 51-78.

43. Kumar, A., Prasad, J.K., Srivastava, N. and Ghosh, S.K. (2019) Strategies to minimize various stress-related freezethaw damages during conventional cryopreservation of mammalian spermatozoa. Biopreserv. Biobank., 17(6): 603-612.

44. Barbas, J.P. and Mascarenhas, R.D. (2009) Cryopreservation of domestic animal sperm cells. Cell Tissue Bank., 10(1): 49-62.

45. Puglisi, R., Bornaghi, V., Severgnini, A., Vanni, R., Montedoro, M. and Galli, A. (2017) Evaluation of two prototype directional freezing methods and a $2 \mathrm{ml}$ flattened straw for cryopreservation of boar semen. Anim. Sci. Pap Rep, 35(4): 397-406.

46. Mutsenko, V., Chasnitsky, M., Sirotinskaya, V., Müller, M., Glasmacher, B., Braslavsky, I. and Gryshkov, O. (2020) Directional Freezing of cell-seeded electrospun fiber mats for tissue engineering applications. In: European Medical and Biological Engineering Conference. Springer, Cham. p391-398.

47. Saragusty, J., Osmers, J.H. and Hildebrandt, T.B. (2016) Controlled ice nucleation is it really needed for large-volume sperm cryopreservation? Theriogenology, 85(7): 1328-1333.

48. Swanson, W.F., Bateman, H.L. and Vansandt, L.M. (2017) Urethral catheterization and sperm vitrification for simplified semen banking in felids. Reprod. Domest. Anim., 52(Suppl 2): 255-260.

49. Magnotti, C., Cerqueira, V., Lee-Estevez, M., Farias, J.G., Valdebenito, I. and Figueroa, E. (2018) Cryopreservation and vitrification of fish semen: A review with special emphasis on marine species. Rev. Aquac., 10(1): 15-25.

50. Baiee, F., Al-Wahab, B.A., Almusawi, A.A., Yu, L.L., Fitri, W.N. and Bustani, G.S. (2020) Effect of vitrification on spermatozoa quality in bull semen. Eur. J Biosci, 14(2): 3897-3904.

51. Bhattacharya, S. (2018) Cryoprotectants and their usage in cryopreservation process. In: Cryopreservation Biotechnology in Biomedical and Biological Sciences. IntechOpen, London. p7.

52. Ghaniei, A., Eslami, M., Hashem, E.Z., Rezapour, R. and Talebi, A. (2019) Quercetin attenuates $\mathrm{H}_{2} \mathrm{O}_{2}$-induced toxicity of rooster semen during liquid storage at $4^{\circ} \mathrm{C}$. J. Anim. Physiol. Anim. Nutr. (Berl), 103(3): 713-722.

53. Liu, C.H., Dong, H.B., Ma, D.L., Li, Y.W., Han, D., Luo, M.J. and Tan, J.H. (2016) Effects of pH during liquid storage of goat semen on sperm viability and fertilizing potential. Anim. Reprod. Sci., 164(1): 47-56.

54. Amin, B.Y., Prasad, J.K., Ghosh, S.K., Lone, S.A., Kumar, A., Mustapha, A.R. and Kumar, A. (2018) Effect of various levels of dissolved oxygen on reactive oxygen species and cryocapacitation-like changes in bull sperm. Reprod. Domest. Anim., 53(5): 1033-1040.

55. Dorado, J., Hidalgo, M., Acha, D., Ortiz, I., Bottrel, M., Azcona, F. and Demyda-Peyrás, S. (2019) Cryopreservation of Andalusian donkey (Equus asinus) spermatozoa: Use of alternative energy sources in the freezing extender affects post-thaw sperm motility patterns but not DNA stability. 
Anim. Reprod. Sci., 208(9): 106126.

56. Hussain, M., Begum, S.S., Kalita, M.K., Ahmed, K.U. and Nath, R. (2018) Additives used in semen preservation in animals: A short review. Int. J. Chem. Stud., 6(5): 354-361.

57. Foote, R.H. and Leonard, E.P. (1964) The influence of pH, osmotic pressure, glycine, and glycerol on the survival of dog sperm in buffered-yolk extenders. Cornell Vet., 54(1): 78-89.

58. Baiee, F., Haron, W., Yusoff, R., Ariff, O., Yimer, N., Hammadi, S. and Kaka, A. (2018) Modification of electro-ejaculation technique to minimise discomfort during semen collection in bulls. Pak. J. Zool., 50(1): 83-89.

59. Malik, A., Jaelani, A., Widaningsih, N., Ni'Mah, G.K. and Sasongko, N. (2018) Effect of different concentrations of fish oil in skim milk-egg yolk extenders on post-thawed semen qualities of Kalang swamp buffalo bull. Asian Pac. J. Reprod., 7(3): 139-142.

60. Mohamed, M.Y., Abd El-Hafeez, A.M. and Shaarawy, A.M. (2019) Influence of adding different energy sources to the bull and ram spermatozoa exposed to different refrigerating times. Egypt. J. Sheep Goats Sci., 14(2): 1-18.

61. Mousavi, S.M., Towhidi, A., Zhandi, M., Amoabediny, G., Mohammadi-Sangcheshmeh, A., Sharafi, M. and Hussaini, S.M.H. (2019) Comparison of two different antioxidants in a nano lecithin-based extender for bull sperm cryopreservation. Anim. Reprod. Sci., 209(10): 106171.

62. Amirat-Briand, L., Bencharif, D., Vera-Munoz, O., Pineau, S., Thorin, C., Destrumelle, S. and Tainturier, D. (2010) In vivo fertility of bull semen following cryopreservation with an LDL (low-density lipoprotein) extender: Preliminary results of artificial inseminations. Anim. Reprod. Sci., 122(3-4): 282-287.

63. Tariq, A., Ahmad, M., Iqbal, S., Riaz, M.I., Tahir, M.Z., Ghafoor, A. and Riaz, A. (2020) Effect of carboxylated poly 1-Lysine as a cryoprotectant on post-thaw quality and in vivo fertility of Nili Ravi buffalo (Bubalus bubalis) bull semen. Theriogenology, 144(4): 8-15.

64. Johnston, S.D., Zee, Y.P., López-Fernández, C. and Gosálvez, J. (2012) The effect of chilled storage and cryopreservation on the sperm DNA fragmentation dynamics of a captive population of koalas. J. Androl, 33(5): 1007-1015.

65. Filho, I.C.B., Pederzolli, C.D., Sgaravatti, A.M., Gregory, R.M., Filho, C.S.D., Jobim, M.I.M. and Mattos, R.C. (2018) Skim milk-egg yolk based semen extender compensates for non-enzymatic antioxidant activity loss during equine semen cryopreservation. Anim. Reprod., 6(2): 392-399.

66. Chaudhari, D.V., Dhami, A.J., Hadiya, K.K. and Patel, J.A. (2015) Relative efficacy of egg yolk and soya milk-based extenders for cryopreservation $\left(-196^{\circ} \mathrm{C}\right)$ of buffalo semen. Vet. World, 8(2): 239-244.

67. Purdy, P.H. (2006) A review on goat sperm cryopreservation. Small Rumin. Res., 63(3): 215-225.

68. Allai, L., Druart, X., Contell, J., Louanjli, N., Moula, A.B., Badi, A. and El Amiri, B. (2015) Effect of argan oil on liquid storage of ram semen in Tris or skim milk based extenders. Anim. Reprod. Sci., 160(9): 57-67.

69. Neuhauser, S., Bollwein, H., Siuda, M. and Handler, J. (2019) Comparison of the effects of five semen extenders on the quality of frozen-thawed equine epididymal sperm. J. Equine Vet. Sci., 79(8): 1-8.

70. Athurupana, R. and Funahashi, H. (2016) Milk supplements in a glycerol free trehalose freezing extender enhanced cryosurvival of boar spermatozoa. Asian Pac. J. Reprod., 5(1): 58-62.

71. Rehman, F.U., Qureshi, M.S. and Khan, R.U. (2014) Effect of soybean based extenders on sperm parameters of Holstein-Friesian bull during liquid storage at $4^{\circ} \mathrm{C}$. Pak. J. Zool., 46(1): 185-189.

72. Vidal, A.H., Batista, A.M., da Silva, E.C.B., Gomes, W.A., Pelinca, M.A., Silva, S.V. and Guerra, M.M.P. (2013) Soybean lecithin-based extender as an alternative for goat sperm cryopreservation. Small Rumin. Res., 109(1): 47-51.

73. Phillips, P.H. (1939) Preservation of bull semen. J. Biol. Chem., 130(1): 415-415.

74. Ashrafi, I., Kia, H.D. and Parrish, J. (2019) Egg yolk saline soluble fraction was as efficient as ammonium sulfate insoluble yolk fraction in cryopreservation of bull semen in comparison with whole egg yolk. Rev. Med. Vet., 170(4-6): 104-109.

75. Sun, L., Fan, W., Wu, C., Zhang, S., Dai, J. and Zhang, D. (2019) Effect of substituting different concentrations of soybean lecithin and egg yolk in tris-based extender on goat semen cryopreservation. Cryobiology, 92(1): 146-150.

76. Amirat, L., Anton, M., Tainturier, D., Chatagnon, G., Battut, I. and Courtens, J.L. (2005) Modifications of bull spermatozoa induced by three extenders: Biociphos, low-density lipoprotein and Triladyl, before, during and after freezing and thawing. Reproduction, 129(4): 535-543.

77. Bergeron, A. and Manjunath, P. (2006) New insights towards understanding the mechanisms of sperm protection by egg yolk and milk. Mol. Reprod. Dev., 73(10): 1338-1344.

78. Tarig, A.A., Wahid, H., Rosnina, Y., Yimer, N., Goh, Y.M., Baiee, F.H. and Ebrahimi, M. (2017) Effect of different concentrations of egg yolk and virgin coconut oil in Tris-based extenders on chilled and frozen-thawed bull semen. Anim. Reprod. Sci., 182(7): 21-27.

79. Simopoulos, A.P. and Salem, N. Jr. (1992) Egg yolk as a source of long-chain polyunsaturated fatty acids in infant feeding. Am. J. Clin. Nutr., 55(2): 411-414.

80. Pace, M.M. and Graham, E.F. (1974) Components in egg yolk which protect bovine spermatozoa during freezing. Anim. Sci. J., 39(6): 1144-1149.

81. Laeni, M., Subagja, J. and Kristanto, A.H. (2020) The Effect of Various Concentration of Quail Egg Yolk on Spermatozoa Motility of Kancra Fish (Tor Soro Valenciennes, 1842) Post Cryopreservation. In: IOP Conference Series: Earth and Environmental Science. Vol. 441. IOP Publishing Ltd., Bristol, United Kingdom. p012060.

82. Akhter, S., Rakha, B.A., Ansari, M.S., Iqbal, S. and Khalid, M. (2018) Evaluation of pigeon egg yolk for post-thaw quality, enzyme leakage and fertility of buffalo (Bubalus bubalis) bull spermatozoa. Theriogenology, 119(7): 137-142.

83. Wulandari, P.D., Subagja, J. and Kristanto, A.H. (2020) Viability of Tor Fish Spermatozoa (Tor Soro, Valenciennes 1842) 48-Hours Cryopreservation: The Effects of Duck Egg Yolk as a Natural Cryoprotectant. In: IOP Conference Series: Earth and Environmental Science. Vol. 441. IOP Publishing Ltd., Bristol, United Kingdom. p012102.

84. Sari, T.P.P., Dasrul, D. and Hamdan, H. (2019) Kualitas spermatozoa sapi aceh pasca pembekuan dengan menggunakan pengencer sitrat kuning telur angsa dengan konsentrasi yang berbeda. (Quality of aceh cattle spermatozoa post-freeze using diluent of goose egg yolk citrate with different concentration). J. Ilmiah Mahasiswa Vet., 4(1): 9-18.

85. Naz, S., Umair, M. and Iqbal, S. (2019) Ostrich egg yolk improves post-thaw quality and in vivo fertility of Nili Ravi buffalo (Bubalus bubalis) bull spermatozoa. Theriogenology, 126(3): 140-144.

86. Saieed, A.Y., Mahdi, Z.A. and Ibrahim, A.A. (2018) Effect of addition from egg yolk of different avian to tris extender on freezing semen traits of Awassi rams. Iraqi J. Agric. Sci., 49(4): 663-669.

87. Swelum, A.A.A., Saadeldin, I.M., Alanazi, M.B., Ba-Awadh, H., Afifi, M. and Alowaimer, A.N. (2018) Effects of adding egg yolks of different avian species to Tris glycerol extender on the post-thawing quality of buck semen. Anim. Reprod. Sci., 195(8): 345-354

88. Moussa, M., Martinet, V., Trimeche, A., Tainturier, D. and Anton, M. (2002) Low-density lipoproteins extracted from hen egg yolk by an easy method: Cryoprotective effect on frozen-thawed bull semen. Theriogenology, 57(6): 1695-1706 
89. Brito, M.F., Neves, B.P., de Oliveira Andrade, G., Gouvêa, R.R., Almeida, J., Morais, C.L. and Henry, M. (2018) Low-density lipoproteins at 2\% concentration can replace whole egg yolk in TES-tris-milk extender for freezing buffalo sperm cells. Acta Sci. Vet., 46(1): 6.

90. Shah, S.A.H., Andrabi, S.M.H., Ahmed, H. and Qureshi, I.Z. (2017) Chicken egg yolk plasma in tris-citric acid extender improves the quality and fertility of cryopreserved water buffalo (Bubalus bubalis) spermatozoa. Theriogenology, 89(2): 32-40.

91. Tshabalala, M.M., Nephawe, K.A., Mphaphathi, M.L., Pilane, C.M. and Nedambale, T.L. (2019). 21 Effect of egg yolk extracted low-density lipoprotein on cryopreserved Nguni bull semen. Reprod. Fertil. Dev., 31(1): 136-136.

92. Ondřej, Š., Jiř́i, Š., Jan, B., Pavla, M.P., Lucie, T., Doležalová, M. and Radko, R. (2019) Low-Density Lipoprotein-important player in increasing cryoprotective efficiency of soybean lecithin-based bull semen extenders. Anim. Reprod., 16(2): 267-276.

93. Crespilho, A.M., Sá Filho, M.F., Dell'Aqua, J.A. Jr., Nichi, M., Monteiro, G.A., Avanzi, B.R. and Papa, F.O. (2012) Comparison of in vitro and in vivo fertilizing potential of bovine semen frozen in egg yolk or new lecithin based extenders. Livest. Sci., 149(1-2): 1-6.

94. Perea, F., Palomares, R., Ferrer, M., Gonzáles, R., Palasz, A., Rosales, J. and Soto-Belloso, E. (2017) A field study to compare post-thaw sperm progressive motility and pregnancy rate using Brahman bull semen frozen in milk based extender containing egg yolk or soybean lipids extract. Clin. Theriogenology., 9(1): 37-46.

95. Tukaram, B.N., Rajagopalan, I.V. and Shartchandra, P.S.I. (2010) The effects of lactose, microcrystalline cellulose and dicalcium phosphate on swelling and erosion of compressed HPMC matrix tablets: Texture analyzer. Iran. J. Pharm. Res., 9(4): 349-358.

96. Rahman, M.S., Gofur, M.R., Rahman, M.M., Bari, F.Y. and Juyena, N.S. (2018) Effect of skim milk and tris-citrate extenders to preserve the semen of indigenous ram of Bangladesh. Asian J. Biol., 5(2): 1-11.

97. Gamal, A., El-Nattat, W.S., El-Sheshtawy, R.I. and El-Maaty, A.M.A. (2016) Substitution of egg yolk with different concentrations of soybean lecithin in tris-based extender during bulls' semen preservability. Asian Pac. J. Reprod., 5(6): 514-518.

98. Miguel-Jimenez, S., del Alamo, M.M.R., ÁlvarezRodríguez, M., Hidalgo, C.O., Peña, A.I., Muiño, R. and Mogas, T. (2020) In vitro assessment of egg yolk-, soya bean lecithin-and liposome-based extenders for cryopreservation of dairy bull semen. Anim. Reprod. Sci., 215(4): 106315.

99. Kumar, P., Kumar, D., Sikka, P. and Singh, P. (2015) Sericin supplementation improves semen freezability of buffalo bulls by minimizing oxidative stress during cryopreservation. Anim. Reprod. Sci., 152(1): 26-31.

100. Pearodwong, P., Suwimonteerabutr, J., Rungruangsak, J. and Tummaruk, P. (2019) Comparison of egg yolk-based and soybean lecithin-based extenders for cryopreservation of boar semen. Vet. Stanica, 50(6): 531-540.

101. Forouzanfar, M., Sharafi, M., Hosseini, S.M., Ostadhosseini, S., Hajian, M., Hosseini, L. and NasrEsfahani, M.H. (2010) In vitro comparison of egg yolkbased and soybean lecithin-based extenders for cryopreservation of ram semen. Theriogenology, 73(4): 480-487.

102. Beccaglia, M., Anastasi, P. and Luvoni, G.C. (2009) Freezing of canine semen in an animal-free protein extender. Vet. Res. Commun., 33(1): 77-80.

103. Stewart, J.L., Shipley, C.F., Katich, A.S., Po, E., Ellerbrock, R.E., Lima, F.S. and Canisso, I.F. (2016) Cryopreservation of white-tailed deer (Odocoileus virginianus) semen using soybean-, liposome-, and egg yolkbased extenders. Anim. Reprod. Sci., 171(8): 7-16.

104. Al-Bulushi, S., Manjunatha, B.M., Bathgate, R.,
Rickard, J.P. and de Graaf, S.P. (2019) Liquid storage of dromedary camel semen in different extenders. Anim. Reprod. Sci., 207(8): 95-106.

105. Oke, M., Jacob, J.K. and Paliyath, G. (2010) Effect of soy lecithin in enhancing fruit juice/sauce quality. Int. Food Res. J., 43(1): 232-240.

106. El-Keraby, F.E., Osman, K., Ganah, H.B. and El-Siefy, E.M. (2010) Soymilk-based extender for cryopreservation of bovine semen. J. Fac. Agric. Kyushu Univ., 1(2): 61-69.

107. Zhang, S., Hu, J., Li, Q., Jiang, Z. and Zhang, X. (2009) The cryoprotective effects of soybean lecithin on boar spermatozoa quality. Afr. J. Biotechnol., 8(22): 6476-6480.

108. Fathi, M., Zaher, R., Ragab, D., Gamal, I., Mohamed, A., Abu-El Naga, E. and Badr, M. (2019) Soybean lecithin-based extender improves Damascus goat sperm cryopreservation and fertilizing potential following artificial insemination. Asian Pac. J. Reprod., 8(4): 174-180.

109. Polge, C., Smith, A.U. and Parkes, A.S. (1949) Revival of spermatozoa after vitrification and dehydration at low temperatures. Nature, 164(4172): 666.

110. Evans, G. and Maxwell, W.M.C. (1987) Salomon's Artificial Insemination of Sheep and Goats (No. 636.30824 E8).

111. Pelufo, V., Armengol, M.L., Malcotti, V., Venturino, A. and Aisen, E.G. (2015) Effects of glycerol and sugar mixing temperature on the morphologic and functional integrity of cryopreserved ram sperm. Theriogenology, 83(1): 144-151.

112. Yang, C.H., Wu, T.W., Cheng, F.P., Wang, J.H. and Wu, J.T. (2016) Effects of different cryoprotectants and freezing methods on post-thaw boar semen quality. Reprod. Biol., 16(1): 41-46.

113. Fernández-Santos, M.R., Esteso, M.C., Montoro, V., Soler, A.J. and Garde, J.J. (2006) Cryopreservation of Iberian red deer (Cervus elaphus hispanicus) epididymal spermatozoa: Effects of egg yolk, glycerol and cooling rate. Theriogenology, 66(8): 1931-1942.

114. Martínez-Pastor, F., Mata-Campuzano, M., ÁlvarezRodríguez, M., Álvarez, M., Anel, L. and De Paz, P. (2010) Probes and techniques for sperm evaluation by flow cytometry. Reprod. Domest. Anim., 45(Suppl 2): 67-78.

115. Hine, T.M., Uly, K., Nalley, W.M. and Armadianto, H. (2019) Frozen sperm quality of bali bulls in modified coconut water extender with different dimethyl sulfoxide concentration. J. Vet., 20(1): 93-100.

116. Rahmatzadeh, M., Kohram, H., Zare Shahneh, A., SeifiJamadi, A. and Ahmad, E. (2017) Antioxidative effect of BHA in soya bean lecithin-based extender containing glycerol or DMSO on freezing capacity of goat semen. Reprod. Domest. Anim., 52(6): 985-991.

117. Lucio, C.D.F., Regazzi, F.M., Silva, L.C.G., Angrimani, D.D.S., Nichi, M. and Vannucchi, C.I. (2016) Oxidative stress at different stages of two-step semen cryopreservation procedures in dogs. Theriogenology, 85(9): 1568-1575.

118. Wu, Z., Zheng, X., Luo, Y., Huo, F., Dong, H., Zhang, G. and Chen, J. (2015) Cryopreservation of stallion spermatozoa using different cryoprotectants and combinations of cryoprotectants. Anim. Reprod. Sci., 163(12): 75-81.

119. Gonzalez-Castro, R.A., Trentin, J.M., Carnevale, E.M. and Graham, J.K. (2019) Effects of extender, cryoprotectants and thawing protocol on motility of frozen-thawed stallion sperm that were refrozen for intracytoplasmic sperm injection doses. Theriogenology, 136(9): 36-42.

120. Martins-Bessa, A., Rocha, A. and Mayenco-Aguirre, A. (2006) Comparing ethylene glycol with glycerol for cryopreservation of canine semen in egg-yolk TRIS extenders. Theriogenology, 66(9): 2047-2055.

121. Taşdemir, U., Büyükleblebici, S., Tuncer, P.B., Coşkun, E., Özgürtaş, T., Aydın, F.N. and Gürcan, I.S. (2013) Effects of various cryoprotectants on bull sperm quality, DNA integrity and oxidative stress parameters. Cryobiology, 66(1): 38-42.

122. Najafi, A., Daghigh-Kia, H., Dodaran, H.V., Mehdipour, M. 
and Alvarez-Rodriguez, M. (2017) Ethylene glycol, but not DMSO, could replace glycerol inclusion in soybean lecithin-based extenders in ram sperm cryopreservation. Anim. Reprod. Sci., 177(2): 35-41.

123. du Plessis, S.S., Agarwal, A., Mohanty, G. and Van der Linde, M. (2015) Oxidative phosphorylation versus glycolysis: What fuel do spermatozoa use? Asian J. Androl., 17(2): 230-235.

124. Arifiantini, R.I., Purwantara, B., Yusuf, T.L. and Sajuthi, D. (2010) Effect of different cryoprotective agents on skim milk and dimitropoulus extender for stallion semen cryopreservation. J. Indones. Trop. Anim. Agric., 35(1): 68-74.

125. Cantanhêde, L.F., de Freitas, E.N., Barros, T.B., Guimarães, D.B., Dias, A.V. and Toniolli, R. (2018) Use of alternative extender added of fructose aiming the cryopreservation of boar semen. Braz. J. Vet. Res. Anim. Sci., 55(1): $1-10$.

126. El-Sheshtawy, R.I., Sisy, G.A. and El-Nattat, W.S. (2015) Effects of different concentrations of sucrose or trehalose on the post-thawing quality of cattle bull semen. Asian Pac. J. Reprod., 4(1): 26-31.

127. Darr, C.R., Varner, D.D., Teague, S., Cortopassi, G.A., Datta, S. and Meyers, S.A. (2016) Lactate and pyruvate are major sources of energy for stallion sperm with dose effects on mitochondrial function, motility, and ROS production. Biol. Reprod., 95(2): 34-31.

128. Sukanya, R., Phubet, S., Srisuwan, C. and Visid, T. (2018) Effects of sugar types in semen extender on sperm quality and longevity of frozen goat semen. J. Int. Soc. Southeast Asian Agric. Sci., 24(1): 152-161.

129. Al-Daraji, H.J. (2012) Effect of adding orange juice into semen diluents on quality and storage ability of cocks' semen. Res. Opin. Anim. Vet. Sci., 2(9): 485-489.

130. Adekunle, E.O., Daramola, J.O., Sowande, O.S., Abiona, J.A. and Abioja, M.O. (2018) Effects of apple and orange juices on quality of refrigerated goat semen. $J$. Agric. Sci. Belgrade, 63(1): 53-65.

131. Gunawan, M., Setiorini, S., Fitri, H.N. and Kaiin, E.M. (2020) The effect of siam orange juice (Citrus nobilis Lour.) in extender on Garut Ram (Ovis aries L.) spermatozoa quality post-cryopreservation. J. Phys. Conf. Ser., 1442(1): 012068 .

132. Khoshvaght, A., Towhidi, A., Zare-shahneh, A., Noruozi, M., Zhandi, M., Davachi, N.D. and Karimi, R. (2016) Dietary n-3 PUFAs improve fresh and post-thaw semen quality in Holstein bulls via alteration of sperm fatty acid composition. Theriogenology, 85(5): 807-812.

133. Malik, A. (2019) Effects of honey supplementation into the extender on the motility, abnormality and viability of frozen-thawed of Bali bull spermatozoa. Asian J. Anim. Vet. $A d v ., 13(2): 109-113$.

134. Ahmed, H., Jahan, S., Khan, A., Khan, L., Khan, B.T., Ullah, H. and Ullah, K. (2020) Supplementation of green tea extract (GTE) in extender improves structural and functional characteristics, total antioxidant capacity and in vivo fertility of buffalo (Bubalus bubalis) bull spermatozoa. Theriogenology, 145(3): 190-197.

135. Mehdipour, M., Kia, H.D., Nazari, M. and Najafi, A. (2017) Effect of lecithin nanoliposome or soybean lecithin supplemented by pomegranate extract on post-thaw flow cytometric, microscopic and oxidative parameters in ram semen. Cryobiology, 78(10): 34-40.

136. El-Sheshtawy, R.I. and El-Nattat, W.S. (2018) Effect of tris-extender supplemented with various concentrations of strawberry (Fragaria spp.) on bull semen preservability. Asian Pac. J. Reprod., 7(2): 93-96.

137. Taşdemir, U., Yeni, D., İnanç, M.E., Avdatek, F., Çil, B., Türkmen, R. and Tuncer, P.B. (2020) Red pine (Pinus brutia Ten) bark tree extract preserves sperm quality by reducing oxidative stress and preventing chromatin damage. Andrologia, 52(6): e13603.

138. Iravani, S. and Zolfaghari, B. (2011) Pharmaceutical and nutraceutical effects of Pinus pinaster bark extract. Res. Pharm. Sci., 6(1): 1-11.

139. Sharma, R.K., Goyal, A.K. and Bhat, R.A. (2013) Antifertility activity of plant extracts on female reproduction: A review. Int. J. Pharm. Biol. Sci., 3(3): 493-514.

140. Bogdanov, S., Jurendic, T., Sieber, R. and Gallmann, P. (2008) Honey for nutrition and health: A review. J. Am. Coll. Nutr., 27(6): 677-689.

141. Fakhrildin, M.B.M. and Alsaadi, R.A. (2014) Honey Supplementation to semen-freezing medium improves human sperm parameters post-thawing. J. Family Reprod. Health., 8(1): 27-31.

142. Yimer, N., Muhammad, N., Sarsaifi, K., Rosnina, Y., Wahid, H., Khumran, A.M. and Kaka, A. (2015) Effect of honey supplementation into tris extender on cryopreservation of bull spermatozoa. Malaysian Anim. Sci. J., 18(2): 47-54.

143. Chung, E.L.T., Nayan, N., Nasir, N.S.M., Hing, P.S.A., Ramli, S., Rahman, M.H.A. and Kamalludin, M.H. (2019) Effect of honey as an additive for cryopreservation on bull semen quality from different cattle breeds under tropical condition. J. Anim. Health Prod., 7(4): 171-178.

144. El-Nattat, W.S., El-Sheshtawy, R.I., El-Batawy, K.A., Shahba, M.I. and El-Seadawy, I.E. (2016) Preservability of buffalo bull semen in tris-citrate extender enriched with bee's honey. J. Innov. Pharm. Biol. Sci., 3(1): 180-185.

145. Zaghloul, A.A. (2017) Relevance of honey bee in semen extender on the quality of chilled-stored ram semen. $J$. Anim. Poult. Prod. Mansoura Univ., 8(1): 1-5.

146. Banday, M.N., Lone, F.A., Rasool, F., Rather, H.A. and Rather, M.A. (2017) Does natural honey act as an alternative to antibiotics in the semen extender for cryopreservation of crossbred ram semen? Iran. J. Vet. Res., 18(4): 258.

147. El-Sheshtawy, R.I., El-Badry, D.A., Gamal, A., El-Nattat, W.S. and Almaaty, A.M.A. (2016) Natural honey as a cryoprotectant to improve Arab stallion post-thawing sperm parameters. Asian Pac. J. Reprod., 5(4): 331-334.

148. Abdi-Benemar, H., Jafaroghli, M., Khalili, B., Zamiri, M.J., Ezazi, H. and Shadparvar, A.A. (2015) Effects of DHA supplementation of the extender containing egg yolk and $\alpha$-tocopherol on the freezability and post-thawing fertility of ram semen. Small Rumin. Res., 130(9): 166-170.

149. Kaeoket, K., Sang-Urai, P., Thamniyom, A., Chanapiwat, P. and Techakumphu, M. (2010) Effect of docosahexaenoic acid on quality of cryopreserved boar semen in different breeds. Reprod. Domest. Anim., 45(3): 458-463.

150. Garmsir, A.K., Shahneh, A.Z. and Nouri, H. (2014) Does Fish Oil Supplementation Improve Fresh and Chilled Sperm Quality of Miniature Caspian Stallion? $1^{\text {st }}$ International Conference on New Ideas in Agriculture. Islamic Azad University, Isfahan, Khorasgan Branch.

151. Habibi, M., Zamiri, M.J., Akhlaghi, A., Shahverdi, A.H., Alizadeh, A.R. and Jaafarzadeh, M.R. (2017) Effect of dietary fish oil with or without Vitamin E supplementation on fresh and cryopreserved ovine sperm. Anim. Prod. Sci., 57(3): 441-447.

152. Gholami, H., Chamani, M., Towhidi, A. and Fazeli, M.H. (2010) Effect of feeding a docosahexaenoic acid-enriched nutriceutical on the quality of fresh and frozen-thawed semen in Holstein bulls. Theriogenology, 74(9): 1548-1558.

153. Masoudi, R., Sharafi, M., Shahneh, A.Z., Towhidi, A., Kohram, H., Zhandi, M. and Shahverdi, A. (2016) Effect of dietary fish oil supplementation on ram semen freeze ability and fertility using soybean lecithin-and egg yolk-based extenders. Theriogenology, 86(6): 1583-1588.

154. Castellano, C.A., Audet, I., Bailey, J.L., Laforest, J.P. and Matte, J.J. (2010) Dietary omega-3 fatty acids (fish oils) have limited effects on boar semen stored at $17 \mathrm{C}$ or cryopreserved. Theriogenology, 74(8): 1482-1490.

155. Brinsko, S.P., Varner, D.D., Love, C.C., Blanchard, T.L., Day, B.C. and Wilson, M.E. (2005) Effect of feeding a DHA-enriched nutriceutical on the quality of fresh, 
cooled and frozen stallion semen. Theriogenology, 63(5): 1519-1527.

156. Maxwell, W.M. and Stojanov, T. (1996) Liquid storage of ram semen in the absence or presence of some antioxidants. Reprod. Fertil. Dev., 8(6): 1013-1020.

157. Gabr, A.A.W. and El Basuini, M.F. (2018) Effect of tonophosphan, zinc oxide, and ascorbic acid on semen, sexual desire, and the fertility rate of Egyptian buffalo bulls. Ann. Agric. Sci., 63(2): 215-221.

158. Al-Gubory, K.H., Fowler, P.A. and Garrel, C. (2010) The roles of cellular reactive oxygen species, oxidative stress and antioxidants in pregnancy outcomes. Int. J. Biochem. Cell Biol., 42(10); 1634-1650.

159. Ansari, M., Zhandi, M., Kohram, H., Zaghari, M., Sadeghi, M. and Sharafi, M. (2017) Improvement of postthawed sperm quality and fertility of Arian rooster by oral administration of d-aspartic acid. Theriogenology, 92(4): 69-74.

160. Hu, J.H., Li, Q.W., Chen, Y.L., Jiang, Z.L., Jia, Y.H., Wang, L.Q. and Ou, B.B. (2009) Effects of addition of Vitamin $B_{12}$ to the extender on post-thaw motility, acrosome morphology, and plasma membrane integrity in bull semen. Turk. J. Vet. Anim. Sci., 33(5): 379-384.

161. Moghbeli, M., Kohram, H., Zare-Shahaneh, A., Zhandi, M., Sharafi, M., Nabi, M.M. and Sharideh, H. (2016) Are the optimum levels of the catalase and Vitamin $\mathrm{E}$ in rooster semen extender after freezing-thawing influenced by sperm concentration? Cryobiology, 72(3): 264-268.

162. Moghbeli, M., Kohram, H., Zare-Shahaneh, A., Zhandi, M., Sharideh, H. and Sharafi, M. (2016) Effect of sperm concentration on characteristics and fertilization capacity of rooster sperm frozen in the presence of the antioxidants catalase and Vitamin E. Theriogenology, 86(6): 1393-1398.

163. Michael, A.J., Alexopoulos, C., Pontiki, E.A., HadjipavlouLitina, D.J., Saratsis, P., Ververidis, H.N. and Boscos, C.M. (2009) Effect of antioxidant supplementation in semen extenders on semen quality and reactive oxygen species of chilled canine spermatozoa. Anim. Reprod. Sci., 112(1-2): 119-135.

164. Hassani-Bafrani, H., Tavalaee, M., Arbabian, M., Dattilo, M. and Nasr-Esfahani, M.H. (2019) The effect of Vitamin $\mathrm{E}$ and Vitamin B on sperm function in rat varicocele model. Andrologia, 51(11): e13429.

165. Silva, S.V., Soares, A.T., Batista, A.M., Almeida, F.C., Nunes, J.F., Peixoto, C.A. and Guerra, M.M.P. (2013) Vitamin E (Trolox) addition to Tris-egg yolk extender preserves ram spermatozoon structure and kinematics after cryopreservation. Anim. Reprod. Sci., 137(1-2): 37-44.

166. Lukusa, K. (2019) Dietary Supplementation of Selenium and Addition of Vitamin $\mathrm{C}$ and $\mathrm{E}$ in Extender to Enhance Semen Cryopreservation and Reproductive Performance of Saanen Goats (Doctoral Dissertation, University of Pretoria).

167. Azawi, O.I. and Hussein, E.K. (2013) Effect of Vitamins C or E supplementation to Tris diluent on the semen quality of Awassi rams preserved at $5 \mathrm{C}$. In: Veterinary Research Forum. Vol. 4. Faculty of Veterinary Medicine, Urmia University, Urmia, Iran. p157.

168. Amini, M.R., Kohram, H., Shahaneh, A.Z., Zhandi, M., Sharideh, H. and Nabi, M.M. (2015) The effects of different levels of Vitamin E and Vitamin C in modified Beltsville extender on rooster post-thawed sperm quality. Cell Tissue Bank, 16(4): 587-592

169. Eidan, S.M. (2016) Effect on post-cryopreserved semen characteristics of Holstein bulls of adding combinations of Vitamin $\mathrm{C}$ and either catalase or reduced glutathione to Tris extender. Anim. Reprod. Sci., 167(4): 1-7.

170. Donnelly, E.T., McClure, N. and Lewis, S.E. (1999) The effect of ascorbate and $\alpha$-tocopherol supplementation in vitro on DNA integrity and hydrogen peroxide-induced DNA damage in human spermatozoa. Mutagenesis, 14(5): 505-512.
171. Resende, C.O., Betarelli, R.P., Rabelo, S.S., Chaves, B.R., Rodriguez-Gil, J.E. and Zangeronimo, M.G. (2019) Addition of insulin-like growth factor I (IGF-I) and reduced glutathione (GSH) to cryopreserved boar semen. Anim. Reprod. Sci., 208(9s): 106130.

172. Yusuf, T.L., Yin, A. and Arifianti, R.I. (2018) The Quality of Sperm in Frozen Dog Semen Prepared Using Modified Tris-Egg Yolk Extender. In: Proceedings of International Seminar on Livestock Production and Veterinary Technology. p299-305.

173. El-Badry, D.A., Gamal, A. and El-Maaty, A.M.A. (2016) Seminal plasma hormonal profile of Arabian stallions that are classified "good" or "poor" for semen freezing. Asian Pac. J. Reprod., 5(6): 453-458.

174. Jamali, N.U., Kaka, A., Khatri, P., Malhi, M., Naeem, M., Memon, A.A. and Kalhoro, D.H. (2019) Effect of in vitro selenium addition to the semen extender on the spermatozoa characteristics before and after freezing in Kundhi buffalo bull and in vivo fertility rate. Pak. J. Zool., 51(1): 317-323.

175. Khalil, W.A., El-Harairy, M.A., Zeidan, A.E. and Hassan, M.A. (2019) Impact of selenium nanoparticles in semen extender on bull sperm quality after cryopreservation. Theriogenology, 126(3): 121-127.

176. Safa, S., Moghaddam, G., Jozani, R.J., Kia, H.D. and Janmohammadi, H. (2016) Effect of Vitamin E and selenium nanoparticles on post-thaw variables and oxidative status of rooster semen. Anim. Reprod. Sci., 174(11): 100-106

177. Kaka, A., Wahid, H., Rosnina, Y., Yimer, N., Khumran, A.M., Sarsaifi, K. and Ebrahimi, M. (2015) $\alpha$-Linolenic acid supplementation in BioXcell ${ }^{\circledR}$ extender can improve the quality of post-cooling and frozen-thawed bovine sperm. Anim. Reprod. Sci., 153(2): 1-7.

178. Bottrel, M., Acha, D., Ortiz, I., Hidalgo, M., Gósalvez, J., Camisão, J. and Dorado, J. (2018) Cryoprotective effect of glutamine, taurine, and proline on post-thaw semen quality and DNA integrity of donkey spermatozoa. Anim. Reprod. Sci., 189(2): 128-135.

179. Malo, C., Crichton, E.G., Morrell, J.M., Pukazhenthi, B.S., Johannisson, A., Splan, R. and Skidmore, J.A. (2018) Colloid centrifugation of fresh semen improves post-thaw quality of cryopreserved dromedary camel spermatozoa. Anim. Reprod. Sci., 192(5): 28-34.

180. Garrett, L.J., Revell, S.G. and Leese, H.J. (2008) Adenosine triphosphate production by bovine spermatozoa and its relationship to semen fertilizing ability. J. Androl., 29(4): 449-458.

181. Berg, H.F., Kommisrud, E., Bai, G., Gaustad, E.R., Klinkenberg, G., Standerholen, F.B. and AlmKristiansen, A.H. (2018) Comparison of sperm adenosine triphosphate content, motility and fertility of immobilized and conventionally cryopreserved Norwegian Red bull semen. Theriogenology, 121(11): 181-187.

182. Amann, R.P. and Waberski, D. (2014) Computer-assisted sperm analysis (CASA): Capabilities and potential developments. Theriogenology, 81(1): 5-17.

183. Longobardi, V., Salzano, A., Campanile, G., Marrone, R., Palumbo, F., Vitiello, M. and Gasparrini, B. (2017) Carnitine supplementation decreases capacitation-like changes of frozen-thawed buffalo spermatozoa. Theriogenology, 88(1): 236-243.

184. Vyklicka, L. and Lishko, P.V. (2020) Dissecting the signaling pathways involved in the function of sperm flagellum. Curr. Opin. Cell Biol., 63(4): 154-161.

185. Blanco, J.M., Long, J.A., Gee, G., Wildt, D.E. and Donoghue, A.M. (2011) Comparative cryopreservation of avian spermatozoa: Benefits of non-permeating osmoprotectants and ATP on turkey and crane sperm cryosurvival. Anim. Reprod. Sci., 123(3-4): 242-248.

186. Giaretta, E., Munerato, M., Yeste, M., Galeati, G., Spinaci, M., Tamanini, C. and Bucci, D. (2017) 
Implementing an open-access CASA software for the assessment of stallion sperm motility: Relationship with other sperm quality parameters. Anim. Reprod. Sci., 176(1): 11-19.

187. Kumaresan, A., Johannisson, A., Al-Essawe, E.M. and Morrell, J.M. (2017) Sperm viability, reactive oxygen species, and DNA fragmentation index combined can discriminate between above-and below-average fertility bulls. Int J. Dairy Sci., 100(7): 5824-5836.

188. Biagi, F., Piras, F., Farina, V., Zedda, M., Mura, E., Floris, A. and Carcupino, M. (2016) Testis structure, spermatogenesis and sperm morphology in pipefishes of the genus Syngnathus. Acta Zool. Fenn., 97(1): 90-101.

189. El-Bahrawy, K., Rateb, S., Khalifa, M., Monaco, D. and Lacalandra, G. (2017) Physical and kinematic properties of cryopreserved camel sperm after elimination of semen viscosity by different techniques. Anim. Reprod. Sci., 187(12): 100-108.

190. Gruhot, T., Gray, K., Brown, V., Huang, Y., Kachman, S.D., Spangler, M.L. and Mote, B. (2019) Genetic relationships among sperm quality traits of Duroc boars collected during the summer season. Anim. Reprod. Sci., 206(7): 85-92.

191. Barth, A.D. and Oko, R.J. (1989) Defects of the sperm tail. In: Abnormal Morphology of Bovine Spermatozoa. Wiley, Hoboken, New Jersey. p214.

192. Chenoweth, P.J. and McPherson, F.J. (2016) Bull breeding soundness, semen evaluation and cattle productivity. Anim. Reprod. Sci., 169(6): 32-36.

193. Murcia-Robayo, R.Y., Jouanisson, E., Beauchamp, G. and Diaw, M. (2018) Effects of staining method and clinician experience on the evaluation of stallion sperm morphology. Anim. Reprod. Sci., 188(1): 165-169.

194. Stival, C., Molina, L.D.C., Paudel, B., Buffone, M.G., Visconti, P.E. and Krapf, D. (2016) Sperm capacitation and acrosome reaction in mammalian sperm. In: Sperm Acrosome Biogenesis and Function During Fertilization. Springer, Cham. p93-106.

195. Hatakeyama, S., Araki, Y., Ohgi, S., Yanaihara, A. and Araki, Y. (2020) Fertilization with human sperm bound to zona pellucida by pressing onto the oocyte membrane. Hum. Cell, 33(3): 521-527.
196. Baskaran, S., Selvam, M.K.P. and Agarwal, A. (2020) Exosomes of male reproduction. In: Advances in Clinical Chemistry. Vol. 95. Elsevier, Amsterdam, Netherlands. p149-163.

197. Salicioni, A.M., Platt, M.D., Wertheimer, E.V., Arcelay, E., Allaire, A., Sosnik, J. and Visconti, P.E. (2007) Signalling pathways involved in sperm capacitation. Soc. Reprod. Fertil. Suppl., 65(3): 245.

198. Talwar, P. and Hayatnagarkar, S. (2015) Sperm function test. J. Hum. Reprod. Sci., 8(2): 61-69.

199. Chen, B., Li, S., Yan, Y., Duan, Y., Chang, S., Wang, H. and Si, W. (2017) Cryopreservation of cynomolgus macaque (Macaca fascicularis) sperm with glycerol and ethylene glycol, and its effect on sperm-specific ion channels CatSper and Hv1. Theriogenology, 104(12): 37-42.

200. Yousef, M.S., López-Lorente, A.I., Diaz-Jimenez, M., Consuegra, C., Dorado, J., Pereira, B. and Hidalgo, M. (2020) Nano-depletion of acrosome-damaged donkey sperm by using lectin peanut agglutinin (PNA)-magnetic nanoparticles. Theriogenology, 151(7): 103-111.

201. Agarwal, A., Gupta, S. and Sharma, R. (2016) Hypoosmotic swelling test (HOS). In: Andrological Evaluation of Male Infertility. Springer, Cham. p93-96.

202. Lamia, A., Daniel, T., Chantal, T., Olivier, G., Jean, L.C. and Marc, A. (2004) Bull semen in vitro fertility after cryopreservation using egg yolk LDL: A comparison with Optidyl1, a commercial egg yolk extender. Theriogenology, 61(5): 895-907.

203. AL-Mudhafar, M.A., Al-Fatlawy, M.A.T., AL-Medhtiy, M.H., Alsharifi, N. and Bustani, G.S. (2020) Calcium administration to improve parturition in dairy cows. Med. Legal Update, 20(4): 885-889.

204. Majzoub, A. and Agarwal, A. (2020) Antioxidants in sperm cryopreservation. In: Male Infertility. Springer, Cham. p671-678.

205. Thananurak, P., Chuaychu-Noo, N., Thélie, A., Phasuk, Y., Vongpralub, T. and Blesbois, E. (2020) Different concentrations of cysteamine, ergothioneine, and serine modulate quality and fertilizing ability of cryopreserved chicken sperm. Poult. Sci. J., 99(2): 1185-1198. 